\title{
Analysis of the Cannibalism in A Madman's Diary
}

\author{
Kefan $\mathrm{Yi}^{1{ }^{1, *}}$ \\ ${ }^{1}$ Teensen Genesis International School, Nanchang 330100, Jiangxi Province, China \\ *Corresponding author.Email: angela@cas-harbour.org
}

\begin{abstract}
The main research direction of this thesis is to explore the interpretation of cannibal imagery on A Madman's Diary. The article will interpret the four-thousand-year concept of "cannibalism" through a view of a madman. This paper will be analyzed from four main parts, which are separately from biological, medical, cultural and philosophical aspects. It is concluded that cannibalism is not merely limited in literal meaning, but has different explanations.
\end{abstract}

Keywords: A Madman's Diary, Lu Xun, Cannibalism, Image

\section{INTRODUCTION}

In the history of mankind, there is a wide ocean of literary works. After the era of cleansing, those works that added value have gradually become classics. They show the world the cultural significance in the context of national history and show the natural course and spiritual genes of the fate of ethnic groups [1]. In May 1918, Lu Xun's first vernacular novel A Madman's Diary was published in the fourth volume, No. 5 of LA JEUNESSE. By focusing on cannibalism, he described the state and mentality of a persecutor, and used a lunatic's diary to point out the cannibalistic nature of feudal etiquette and the feudal system. As the general preface of the May 4th New Culture Movement in China, the work represents the awakening of modern people's consciousness and the counterattack against various irrational systems in the tradition as well as the decadent culture that suppresses human nature. By analyzing the article, the author will build a clear structure about $A$ Madman's Diary, as well as allow the readers to know more about the specific meaning in cannibalism.

\section{ANALYSIS OF CANNIBALISM}

\subsection{Biological Cannibalism-Man and Animals in the Same Structure}

In this world of irrational madman, Lu Xun constructed his personal myth. There are two series in the myth. The first one includes Zhao's dog, steamed fish, chicken, duck, lion, rabbit, fox, hyena, etc. The second series covers Zhao Guiweng, elder brother, doctor $\mathrm{He}$,
Chen Laowu, pedestrians, children, even the madman himself. In the novel, readers are constantly hinted that whether it is the animal world or the human society, it is actually a world dominated by the animal nature or in another word, the survival of the fittest. Thus, humans and animals are basically the same. Any person or beast who wants to attack or eat other people or beasts, at the same time will be attacked or eaten by other people or beasts. It is precisely under this mentality of "I want to eat people, but I am afraid of being eaten by others", so their eyes are always "seems to be afraid of me, as if they want to harm me".

In chapter eight, the madman uses the mouth of young people to point out the idea that "people will eat people in famine years". At that time, wars or poor harvests often resulted in food shortages, so the masses could not afford to buy food, which leads to the exchange of children. Theoretically, when children are sold for food, the children are still children, but the children who are exchanged for other children are no longer "people" but "food". In this way, children can be directly killed and eaten without psychological burden. Children are deprived of their rights as individuals and their rights to survive, only become food that parents exchange for survival. Here $\mathrm{Lu}$ Xun exposes the nature of the nation facing desperate situation-exchanging children to eat. There is no difference between humans and animals,as they all eat the congener in famine years to survive.

In the letter that $\mathrm{Lu}$ Xun wrote to his friend $\mathrm{Xu}$ Zhangshou on August 20th, 1918. He said that " $A$ Madman's Diary was basically a terrible work, since reading "tongjian" tells me that the Chinese are still cannibals". Lu Xun expressed the discovery of Chinese 
belonging to cannibal through the illusion of a mad man. As a nation of cannibal, the nature of beast certainly keeps a dominating position.

\subsection{Medical Cannibalism - to Treat Diseases}

Through the view of a mad man, Lu Xun ingeniously conveyed a point that "eat people could cure diseases". At the same time, as a mad man, he vaguely used the contradictory concept of Materia Medica to insinuate the absurdity of the statement. In the history, "Materia Medica written by Li Shizhen" undoubtedly was referred to Compendium of Materia Medica. However, there was another Supplement to Materia Medica, which was written by Chen Cangqi in Tang dynasty. Li Shizhen wrote that in Supplement to Materia Medica: Chen Cangqi, who was from Mingzhou, recorded that flesh of people was able to treat the focus of tubercular infection, which was tuberculosis actually and could never be cured in the past. Lu Xun's father died of this disease. Hua Xiaoshuan, one of the characters in Medicine (another famous novel written by $\mathrm{Lu}$ Xun) also suffered from this disease. Although Hua had eaten the buns with Xia Yu's blood (Xia Yu is another character in this novel), he still died.

In Chen Cangqi's Supplement to Materia Medica, it was believed that human flesh could cure tuberculosis. However, Li Shizhen was opposed to this point. He argued that "Our body skin is given by parents, so dare not damage. Even if the parents are seriously ill, why would they want to eat the flesh of their children's disabled bodies?" In Madman's diary, the madman was confused by Li Shizhen and Chen Cangqi, as well as Compendium of Materia Medica and Supplement to Materia Medica, but the beauty is that it allows readers to make associations. For example, even though $\mathrm{Li}$ Shizhen does not advocate the use of human flesh to cure diseases, Chen Cangqi does. It is true that there is such a claim, and Chen is certainly not the only physician who advocated this way, and the medical book that advocated this point is more than one Supplement to Materia Medica. Even Li Shizhen himself does not oppose all the use of people as "medicine" [5]. Compendium of Materia Medica has a specific volume which is directly related to people, with more than 30 entries under it, and all of which are related to the human body, such as human blood, human bone and human cell. For these so-called prescriptions, Li Shizhen sometimes denounced them, but sometimes did support them. For instance, he believes that although killing people and taking one's gallbladder is a cruel act that "gentlemen would not do", but taking gallbladder in the battlefield is "harmless and reasonable". He also believes that those who take human blood as medicine are insensitive, but still listed seven prescriptions for them. Hence, it seems that when a madman says that Li Shizhen's Materia Medica says
"Human flesh can be eaten", it is not considered to be a false accusation.

It can be inferred that human flesh might cure diseases to some extent so in the field of medicine, "eating people" could be somewhat reasonable.

\subsection{Cultural Cannibalism-Loyalty to Etiquette}

In the novel, the best example to display loyalty to etiquette is the young person who talks with the mad man. In the eighth chapter of $A$ Madman's Diary, when a young man, who is about twenty years old, faces the questioning of the madman and regards "always like this" as a legitimate reason for cannibalism. When the truth about cannibalism cannot be concealed, it can only be prevaricated by saying "It has always been like this" in order to form discourse hegemony. This is actually a typical manifestation of the unified ideology of feudal ethics, which is aimed at uniting all people and eliminating the individual independent thinking generally. Chinese people have lost their ability to think and rational spirit from beginning to end. They only know that they have been like this since ancient times. They only know that people follow the "ancestral law" and form a collective unconsciousness. They have never thought about the rationality of these practices. They are ignorant and have no spirit of speculation and the words they said are just seemingly quotient, but in fact quite unreasonable.

In addition to these blatantly "cannibalistic" people, there are also people who wear loyal and filial skin but have intent on cannibalism. The novel has repeatedly mentioned "cutting of bones to treat relatives", which stems from the medical superstition that human flesh can cure diseases, but is put on a warm and affectionate veil of "filial piety", so that the cannibals can "eat" people comfortably, and the voluntarily "eaten" people could have a lofty sense of "sacrifice". For instance, in chapter eleven, the eldest brother cut off the flesh of himself and the madman to treat their parents. The mother did not stopped them, but even swallowed a whole piece of meat. The coverage of this veil is extremely wide, not only limited to the people in small towns without independent thinking ability in novel $A$ Madman's Diary, but also a large number of daughters and sons who "cut stocks to save the father" or "cut liver to save mother" in the records of official histories and local chronicles. Why Lu Xun explained this social reality from the perspective of a madman, and why the philosophy of "cannibalism" that normal people cannot question can only be seen by the mentally ill "madman"? Because the collective abnormality of a nation's general pathological psychology is far inferior to the calmness with people who are mentally ill. The disadvantage of the family system and ethics is to eliminate the most sincere feelings between people by using the so-called "filial piety" to stereotype people's feelings, so that the Chinese would lose their 
sympathy for the same kind and the fundamental judgment to tell right and wrong, even only looking for happiness from the suffering of others, thus becoming ignorant, forgetful, and insensitive, which are also the root of our nation's suffering.

If we entitle cannibalism in the name of filial piety, its impact may be only confined to the family, then cannibalism in the name of loyalty may influence the entire country. In the story "Yi Ya Steaming his Child", Yi Ya showed loyalty to Qi Huan at the expense of his young son, and he gained power. After that, he joined forces with Shu Diao to launch a coup d'etat, then the country of Qi fell into turmoil. There is another example. During the Anshi Rebellion, Zhang Xun and Xu Yuan did not hesitate to "take people as food" in order to defend Suiyang City. As a result, twenty to thirty thousand women, children, old and weak were killed by their families. Furthermore, in addition to the relationship between relatives, monarchs and ministers, the slavery relationship between members of society is also implied in A Madman's Diary.

Those people, some of whom have been pilloried by the magistrate, slapped in the face by the local gentry, had their wives taken away by bailiffs or their parents driven to suicide by creditors, never looked as frightened and as fierce then as they did yesterday [6]. The fear and viciousness of normal people towards madmen, who are trying to subvert order, is even greater than the emotions when they are persecuted by order [2]. Such stubborn rejection of dissidents made this group of normal people feel at ease to "eat people", who are covered with the skin of feudal ethics. It can be seen that "eating" and "being eaten" have gradually penetrated into all aspects of feudal society. No matter whether people hide their "cannibalistic" nature or not, feudal ethics has become a deep-rooted existence-"Perhaps it is there, and it has always been like this".

Even more frightening thing is that this cannibalistic "loyalty and filial piety" has entered Chinese literature and has been beautified. In Romance of the Three Kingdoms and Water Margin, which are well-known by Chinese people, all have some cannibals hidden under the skin of loyalty and filial piety. For example, in the nineteenth chapter of The Romance of the Three Kingdoms, there was such a story that "Liu Bei was defeated by Rubles and wanted to seek shelter from Cao Cao. On the way, he lived in the home of Liu An, who was a hunter. Liu An admired Liu Bei very much and wanted to fight with him, but there was an old mother at home. In order to fulfill his filial piety, he could not go. So Liu An had to "kill his wife to eat them." In this way, he realized the highest Confucian thought-loyalty and filial piety by "cannibalism". The author clearly wrote that in the tone of praise, and when readers look at it, there is no excessive spiritual fluctuation, indicating that such thoughts have slowly penetrated into history. In modern life, things like those "foolish loyalty, foolish filial piety" are actually quite common. Under the noble name, Li Xiangqun, the hero of fighting the flood with disease and sandbags, Lai Ning, a teenager who protects the national collective property, become the moral model in citizens mind, but what people ignored is that this is virtually the expression of the lack of awe for people's lives, as well as the trampling of the supreme value of people's lives. The cannibalism in this article is an absolute representation of death and sacrifice. Death is the end, and it requires a wholeness of mind, in which one's own life, including one's own, must be sacrificed for the purpose of the whole. Obviously, Lu Xun was totally against the students' taking to the streets. He said the revolution would require sacrifice, but he emphasized the lives of young people - that reform is not synonymous with bloodshed, but with bloodshed [3].

\subsection{Philosophical Cannibalism- Contradiction of Notion}

It can be known from Darwin's theory of evolution that the Chinese nation is still a barbaric nation in cannibalism [4]. But after all, human civilization is constantly improving, and one day the Chinese nation will stop cannibalism, with the cannibals eventually becoming extinct. There is an extract from the novel.

Old Chen came in too, in a great temper, but they could not stop my mouth, I had to speak to those people:

"You should change, change from the bottom of your hearts!" I said. "You must know that in the future there will be no place for man-eaters in the world".

"If you don't change, you may all be eaten by each other. Although so many are born, they will be wiped out by the real men, just like wolves killed by hunters. Just like reptiles"[6]!

The madman's thinking is clear and profound as he has considered and analyzed the cannibalism in China and even the whole of mankind. He has created great courage in doubt and fear, trying to make his big brother and the people around him think and reflect and encourage them to get out of this cannibalistic state and become real people.

However, if one starts from the concept of original sin, the concept of "cannibalism" is handed down from the generation of ancestors. Passing on to the present, it will continue to flow like blood for a long time. The novel mentions a lot of "cannibalism" incidents, the oldest one should be "Yi Ya Steaming his Child". Yi Ya steamed his son and served it to Jiezhou, the same thing as before [6]. There is an error of common sense here. Yi Ya dedicated his son to Qi Huangong instead of Jie Zhou. However, since the madman is a neuropathic patient, it is inevitable that "the language is quite mixed and incoherent", which is in line with the pathogenesis of neurology. And this 
mistake is a wonderful thing. Since there was "cannibalism" in the Spring and Autumn Period, it was possible that there was "cannibalism" in the Xia and Shang dynasty, which was even more distant than this. The history dated back for at least one or two thousand years, and has been pushed back to the initial stage of the Chinese dynasty. There is also a "error" in the article. Xu Xilin, a fellow of Lu Xun, stabbed Enming governor of Anhui to death in 1907, and his heart and liver were fried by the Enming Guard. This incident is the most recent "cannibalism" incident in the era mentioned by the madman, and it is time for the era of the Chinese dynasty to come to an end. From the Xia and Shang to the late Qing Dynasty, the beginning and the end were counted, and there was almost four thousand years apart. Therefore, the madman would lament that he has "four thousand years of cannibalism".

\section{CONCLUSION}

A Madman's Diary, as the first famous novel in the history of Chinese modern literature, combines the spirit of anti-feudalism with a new and perfect art form, which deeply reflects the actual achievements of ideological revolution and literary revolution. After a long observation of semi-colonial and semi-feudal old China, Lu Xun gives cannibalism a real and also a symbolic meaning. For reality, it happened in the poor era when people exchange their children, as well as in medical research for curing diseases. For symbolism, cannibalism represents the loyalty, filial piety, original $\sin$ and evolutionism. To put it into a nutshell, with the help of Lu Xun's mature writing proficiency and profound content communication, this outstanding modern literary work quickly became the ideological enlightenment of the New Culture Movement, which positively influences a lot of people.

\section{ACKNOWLEDGMENTS}

First and foremost, I would like to show my deepest gratitude to my teachers and professors, who have provided me with valuable guidance in every stage of the writing of this thesis. Further, I would like to thank my friends and parents for their encouragement and support. Without all their enlightening instruction and impressive kindness, I could not have completed my thesis.

\section{REFERENCES}

[1] Rereading Classics with Cultural Confidence-On Lu Xun's “A Madman's Diary” and Nikolai Gogol's "Diary of a Madman" 2017, pp. 512-515.

[2] D. J. Wang, The Theme and Essence of Man-eating Image in A Madman's Diary, Journal of HuBei TV University, January 2010.
[3] L. Q. Qian, et al. Thirty Years of Modern Chinese Literature [M]. Beijing, Peking University Press, 2005.

[4] Carlos Rojas, Immunization and community, Journal of University of Jinan (Social Science Edition) 2017, pp.19-25.

[5] W. J. Yang, Four thousand years of "civilization" or four thousand years of "cannibalism", Journal of Hunan Normal University, 2019.

[6] X. Lu, A Madman's Diary, online available, https://www.thn21.com/middle/gs/8805.html, accessed on January 10th, 2021. 